\title{
Perancangan Deteksi Banjir Menggunakan Sensor Kapastif Mikrokontroler ATMega328p dan SMS Gateway
}

\author{
Widy Astuti ${ }^{1}$ Abdurahman Fauzi ${ }^{2}$ \\ ${ }^{1}$ Universitas BSI \\ e-mail : widy.yagami@gmail.com \\ ${ }^{2}$ STMIK Nusa Mandiri \\ e-mail : abdurahman.auz@bsi.ac.id
}

\begin{abstract}
Abstrak
Permasalahan yang sering terjadi pada lingkungan masyarakat adalah kesulitan untuk mendeteksi mengenai akan datangnya banjir secara dini, sehingga berdampak pada kerugian materil dan korban jiwa. Untuk itu diperlukan suatu sistem yang dapat mendeteksi banjir secara dini agar masyarakat dapat langsung mengetahui informasi peringatan yang cepat dan efektif sehingga dapat melakukan antisipasi dini dengan penyelamatan diri atau barang yang berharga.Dengan menggunakan sensor kapasitif yang terbuat dari dua buah lempeng PCB yang diberi batas-batas tertentu untuk mengukur ketinggian air sungai serta dilengkapi teknologi SMS Gateway menggunakan Modul SIM 800L yang memungkinkan sistem dapat mengirimkan informasi peringatan banjir secara dini langsung ke handphone melalui SMS. Rancang bangun alat deteksi banjir ini dibuat sedemikian rupa dengan melakukan percobaan yaitu membuat suatu prototipe dengan tabung air yang telah diterapkan sensor kapasitif berbasis mikrokontroler yang didalamnya terdapat sebuah program Bahasa $\mathrm{C}$ yang sudah di compile. Mikrokontroler ATMega328p akan membaca sensor kapasitif berdasarkan nilai kapasitansi air. Data tersebut akan diproses oleh mikrokontroler ATMega328p dan melakukan perintah output melalui LCD, LED, dan buzzer untuk menampilkan status dari ketinggian permukaan air sungai.Dari prototipe sebuah tabung air yang diterapkan sensor kapasitif sebagai sensor deteksi banjir berbasis mikrokontroler dan SMS Gateway telah berhasil dibuat dan dapat berjalan dengan baik sesuai dengan yang diharapkan. Ketika air mencapai batas aman maka lampu LED hijau menyala, pada batas siaga maka LED kuning menyala dan mengirimkan sms peringatan, serta pada batas bahaya maka LED merah menyala dan mengirim sms juga buzzer menyala.
\end{abstract}

Kata Kunci: Alat Deteksi Banjir, Mikrokontroler, SMS Gateway

\begin{abstract}
Problems that often occur in the community are difficult to detect about the arrival of flooding early, so that it has an impact on material loss and loss of life. For this reason, a system that can detect flooding early is needed so that people can immediately find out information about warnings that are fast and effective so they can do early anticipation by rescuing themselves or valuable items. By using a capacitive sensor made of two PCB plates that are bounded certain limits for measuring river water level and equipped with SMS Gateway technology using the $800 \mathrm{~L}$ SIM Module that allows the system to send flood warning information early directly to the handphone via SMS, the design of this flood detection device is made in such a way as to do an experiment that is to make a prototype with a tube water that has been applied is a microcontroller-based capacitive sensor in which there is a $C$ language program that has been compiled. ATMega328p microcontroller will read capacitive sensors based on the value of water capacitance. The data will be processed by the ATMega328p microcontroller and perform output commands via $L C D, L E D$, and buzzer to display the status of the river water level. goes well as expected. When the water reaches the safe limit, the green LED lights on, at the standby limit, the yellow LED lights up and sends an SMS alert, and at the danger limit, the red LED lights up and sends an SMS also the buzzer lights up.
\end{abstract}

Keywords: Flood Detection Tool, Microcontroller, SMS Gateway. 


\section{Pendahuluan}

Berdasarkan Undang-Undang No 24 tahun 2007 Pasal 1 ayat (1) bencana didefinisikan sebagai peristiwa atau rangkaian peristiwa yang mengancam dan mengganggu kehidupan dan penghidupan masyarakat yang disebabkan baik oleh faktor alam dan atau faktor non alam maupun faktor manusia sehingga mengakibatkan timbulnya korban jiwa manusia, kerusakan lingkungan, kerugian harta benda, dan dampak psikologis.

Perubahan iklim global, perubahan penggunaan lahan dan meningkatnya jumlah penduduk makin memperbesar ancaman risiko bencana di Indonesia. Salah satu bencana di Indonesia yang sering terjadi setiap tahunnya adalah banjir. Dari data dan informasi bencana indonesia oleh Badan Nasional Penanggulangan Bencana (BNPB) mengenai bencana banjir dari tahun 1985 hingga sekarang tercatat sebanyak 695 jumlah kejadian dan dalam kurun waktu 10 tahun terakhir (Tahun 2007 hingga 2017) rata-rata presentase mencapai angka $31,4 \%$ dari total bencana di Indonesia.

Banjir adalah meluapnya aliran sungai akibat air melebihi kapasitas tampungan sungai sehingga meluap dan menggenangi daratan atau suatu daerah yang lebih rendah di sekitarnya (Yulaelawati, 2008).

Jawa Barat merupakan salah satu wilayah di Indonesia yang sering mengalami bencana alam. Salah satu daerahnya adalah Dayeuhkolot, Kabupaten Bandung. Bencana alam yang seringkali dihadapi oleh masyarakat Dayeuhkolot adalah banjir. Setiap turun hujan, maka daerah ini akan terendam oleh air. Lebihlebih jika intensitas curah air hujan cukup tinggi dan berdurasi lama, maka dapat dipastikan banjir akan melanda. Bencana banjir beresiko tinggi mengancam keselamatan jiwa para warga serta merusak infrastruktur yang ada. Bukan hanya kerugian secara materi yang menjadi masalah, namun juga dampak psikologis (Taufiq, Susanty, S, \& Nurlina, 2014).

Berdasarkan uraian di atas maka dirancang suatu alat untuk mengukur ketinggian air dengan menggunakan sensor kapasitif yang diaplikasikan pada sebuah prototipe tabung berisi air. Sebagai antarmuka digunakan mikrokontroler ATMega328p dan memanfaatkan teknologi sms gateway sebagai pengirim informasi secara cepat dan tepat.

Pada perancangan alat digunakan beberapa komponen pendukung sehingga alat dapat berfungsi dengan baik ketika dioperasikan. Adapun komponenkomponen pendukung yang digunakan pada perancangan alat deteksi banjir, yaitu

\section{Sensor Kapasitif}

Sensor kapasitif merupakan sensor elektronika yang bekerja berdasarkan konsep kapasitif. Sensor ini juga bekerja berdasarkan perubahan muatan energi listrik yang dapat disimpan oleh sensor akibat perubahan jarak lempeng, perubahan luas penampang dan perubahan volume dielektrikum sensor kapasitif tersebut (Nuwaiir,2009).

Sifat-sifat sensor kapasitif yang dimanfaatkan dalam pengukuran adalah:

1. Jika luas permukaan dan dielektrika (udara) konstan, maka perubahan nilai kapasitansi ditentukan oleh jarak antara kedua lempeng logam.

2. Jika luas permukaan dan jarak kedua lempeng logam konstan dan volume dielektrikum dapat dipengaruhi maka perubahan kapasitansi ditentukan oleh volume atau ketinggian cairan elektrolit yang diberikan.

3. Jika jarak dan dielektrikum (udara) konstan, maka perubahan kapasitansi ditentukan oleh luas permukaan kedua lempeng logam yang saling berdekatan.

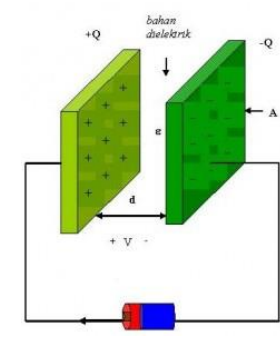

Gambar 1. Rangkaian sensor kapasitif.

(Sumber : Elektronika Dasar, 2016)

Kontruksi sensor kapasitif yang digunakan berupa dua buah lempeng logam yang diletakkan sejajar dan saling berhadapan. Jika diberi beda tegangan antara kedua lempeng logam tersebut, maka akan timbul kapasitansi antara kedua logam, berbanding terbalik dengan jarak 
antara kedua lempeng dan berbanding lurus dengan zat antara kedua lempeng tersebut (dielektrika), seperti ditunjukkan oleh persamaan berikut :

Dimana :

$$
C=\varepsilon_{0} \varepsilon_{r} \frac{A}{d}
$$

$\varepsilon_{r}:$ permitivitas ruang hampa $\left(8,85.10^{-}\right.$

$\left.{ }^{12} \mathrm{~F} / \mathrm{m}\right)$

$\varepsilon_{r}:$ permitivitas relatif (udara $=1$ )

$A$ : luas plat/lempeng dalam $\mathrm{m}^{2}$

$d$ : jarak antara plat /lempeng dalam $\mathrm{m}$

\section{Buzzer}

Buzzer adalah sebuah komponen elektronika yang berfungsi untuk mengubah getaran listrik menjadi getaran suara. Pada dasarnya prinsip kerja buzzer hampir sama dengan loud speaker, jadi buzzer juga terdiri dari kumparan yang terpasang pada diafragma dan kemudian kumparan tersebut dialiri arus sehingga menjadi elektromagnet, kumparan tadi akan tertarik ke dalam atau keluar, tergantung dari arah arus dan polaritas magnetnya, karena kumparan dipasang pada diafragma maka setiap gerakan kumparan akan menggerakkan diafragma secara bolakbalik sehingga membuat udara bergetar yang akan menghasilkan suara, Buzzer biasa digunakan sebagai indikator bahwa proses telah selesai atau terjadi suatu kesalahan pada sebuah alat (alarm) (Pratama \& Aqwam Rosadi Kardian, 2012)

\section{LCD (Liquid Crystal Display)}

LCD merupakan salah satu komponen elektronika yang berfungsi sebagai tampilan suatu data, baik karakter, huruf, atau grafik. LCD membutuhkan tegangan dan daya yang kecil sehingga sering digunakan untuk aplikasi pada kalkulator, arloji digital, instruen elektronik seperti multimeter digital. LCD memanfaatkan silikon dan galium dalam bentuk kristal cair sebagai pemendar cahaya. Pada layar LCD, setiap matrik adalah susunan dua dimensi piksel yang dibagi dalam baris dan kolom. Dengan demikian, setiap pertemuan baris dan kolom terdiri dari LED pada bidang latar (backplane), yang merupakan lempengan kaca bagian belakang dengan sisi dalam yang ditutupi oleh lapisan elektroda transparan. Dalam keadaan normal, cairan yang digunakan memiliki warna cerah. Kemudian daerah-daerah tertentu pada cairan tersebut warnanya akan berubah menjadi hitam ketika tegangan diterapkan antara bidang latar dan pola elektroda yang terdapat pada sisi dlam kaca bagian depan. Keunggulan menggunakan LCD adalah konsumsi daya yang relatif kecil dan menarik arus yang kecil (beberapa mikro ampere), sehingga alat atau sistem menjadi portable karena dapat menggunakan catu daya yang kecil. Keunggulan lainnya adalah ukuran LCD yang pas yakni tidak terlalu kecil dan tidak terlalu besar, kemudian tampilan yang diperlihatkan dari LCD dapat dibaca dengan mudah dan jelas (Setiawan,2010).

\section{Light Emitting Diode (LED)}

Light Emitting Diode atau sering disingkat dengan LED adalah komponen elektronika yang dapat memancarkan cahaya monokromatik ketika diberikan tegangan maju. LED merupakan keluarga dioda yang terbuat dari bahan semikonduktor. Warna-warna cahaya yang dipancarkan oleh LED tergantung pada jenis bahan semikonduktor yang dipergunakannya. LED juga dapat memancarkan sinar inframerah yang tidak tampak oleh mata seperti yangsering kita jumpai pada remote control TV ataupun remote control perangkat elektronik lainnya (Kho, 2015).

\section{Modul GSM SIM 800L}

Sebuah modul GSM adalah jenis khusus dari modem yang menerima kartu SIM, dan mengoperasikan lebih dari berlangganan ke operator selular, seperti mobile phone. Dari prespektif operator seluler, modul GSM terlihat seperti telepon genggam.

\section{Mikrokontroler ATMega 328p}

ATMega328 merupakan mikrokontroler keluarga AVR 8 bit. Beberapa tipe mikrokontroler yang sama dengan ATMega8 ini antara lain ATMega8535, ATMega16, ATMega32, ATMega328, yang membedakan antara mikrokontroler antara lain adalah ukuran memori, banyaknya GPIO (pin input/output), peripheral (USART, timer, counter, dill). Dari segi ukuran fisik, ATMega328 memiliki ukuran fisik lebih kecil dibandingkan dengan beberapa mikrokontroler diatas. Namun untuk segi memori dan peripheral lainnya ATMega328 tidak kalah dengan yang lainnya karena ukuran memori dan peripheral-nya relatif sama dengan ATMega8535, ATMega32, 
hanya saja jumlah GPIO lebih sedikit dibandingkan mikrokontroler lainnya.

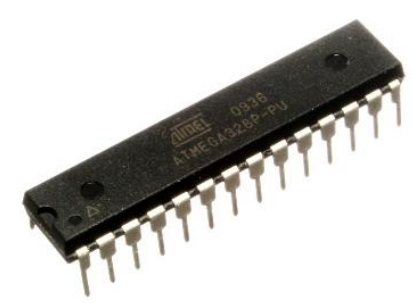

Gambar 2. Mikrokontroler ATMega328p

(Sumber : Harry Ardiana, 2017)

ATMega328 adalah mikrokontroler keluaran dari atmel yang mempunyai arsitektur RISC (Reduce Instruction Set Computer ) yang dimana setiap proses eksekusi data lebih cepat dari pada arsitektur CISC (Completed Instruction Set Computer). Mikrokontroler ATMega328 memiliki arsitektur Harvard, yaitu memisahkan memori untuk kode program dan memori untuk data sehingga dapat memaksimalkan kerja dan parallelism. Instruksi-instruksi dalam memori program dieksekusi dalam satu a;ur tunggal, dimana pada saat satu instruksi dikerjakan instruksi berikutnya sudah diambil dari memori prgram.

Konsep inilah yang memungkinkan instruksi-instruksi dapat dieksekusi dalam siklus clock.32 x 8-bit register serba guna digunakan untuk mendukung operasi pada ALU (Aritmatika Logic Unit) yang dapat dilakukan dalam satu siklus. 6 dari register serbaguna ini dapat digunakan sebagai 3 buah register pointer 16 -bit pada mode pengalamatan tak langsung untuk mengambil data pada ruang meori data. Ketiga register pointer 16 -bit ini disebut dengan register $X$ (gabungan $\mathrm{R} 26$ dan $R 27)$, register $Y$ (gabungan R28 dan R9), dan register $Z$ (gabungan $R 30$ dan $R 31$ ).

Hampir semua instruksi AVR memiliki format 16-bit. Setiap alamat memori program terdiri dari instruksi 16-bit atau 32-bit. Selain register serba guna di atas, terdapat register lain yang dipetakan dengan teknik memory mapped I/O selebar 64 byte. Beberapa register ini digunaka untuk fungsi khusus antara lain sebagai register control Timer/ Control, Interupsi, ADC, USART, SPI, EEPROM, dan fungsi I/O lainnya. Register-register ini menempati memori pada alamat $0 \times 20 \mathrm{~h}-0 \times \mathrm{Fh}$.

\section{Metode Penelitian}

Rangkaian diagram alat deteksi banjir menjelaskan mengenai alur dari setiap komponen yang digunakan seperti sensor kapasitif, LED,LCD, dan modul GSM yang sebelumnya sudah diprogram menggunakan ATMega328p.

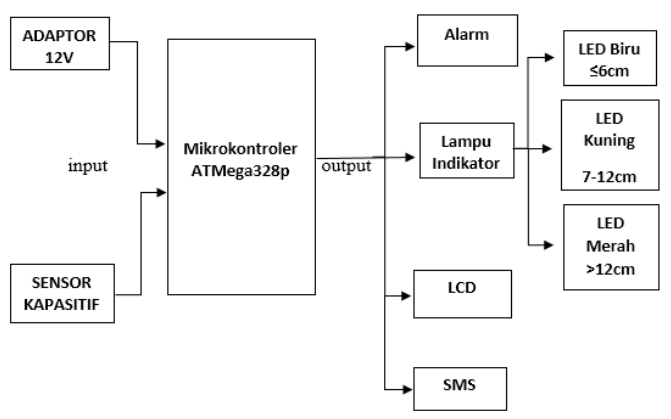

Gambar 3. Rangkaian Diagram Alat Deteksi Banjir

\section{Hasil dan Pembahasan}

\section{Rangkaian Mikrokontroler}

Pada perencanaaan mikrokontroler penulis menggunakan IC ATMega328p sebagai pusat kontrol mulai dari input, proses dan output. Mikrokontroler ATMega328p merupakan mikrokontroler yang mempunyai arsitektur RISC (Reduce Instruction Set Computer) yang dimana setiap proses eksekusi data lebih cepat dari pada arsitektur CISC (Completes Instruction Set Computer). Mikrokontroler ini dipilih karena memiliki 14 pin $\mathrm{I} / \mathrm{O}$ dua arah, 1 KB memori EEPROM (Electrectrically Erasabble Programmable Read Only Memory), data dapat dibaca dari memori apabila catu daya dimatikan, data terakhir yang ditulis pada memori EEPROM masih tersimpan pada memori (nonvolatile).

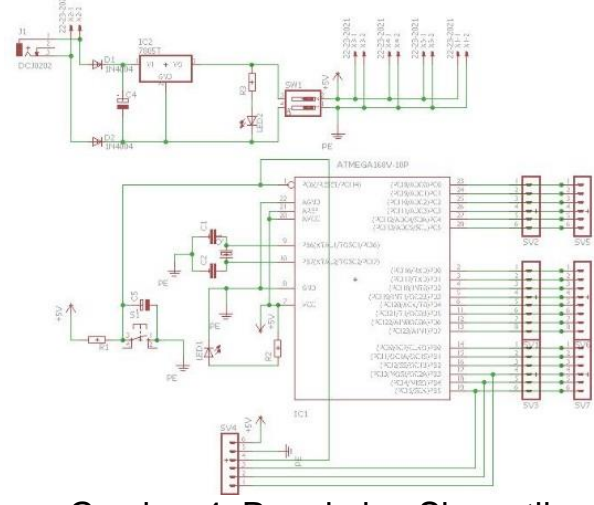

Gambar 4. Rangkaian Skematik Mikrokontroler ATMega328p. 


\section{Rangkaian Catudaya}

Rangkaian sistem minimum ATMega328p membutuhkan sumber tegangan, adaptor 12 volt digunakan sebagai sumber tegangan ke sistem minimum yang dilengkapi dengan rangkaian penurun tegangan 5 volt (IC regulator 7805)supaya tegangan tidak melebihi 5 volt yang mengakibatkan kerusakan pada komponen-komponen lainnya.

Dalam membuat catu daya DC, digunakan power supply untuk alat yang digunakan,maka penulis membutuhkan sebuah rangkaian untuk menurunkan tegangan dari DC ke DC, karena alat yang dibuat membutuhkan tegangan 5 volt.rangkaian penurun tegangan tersebut menggunakan komponen-komponen sebagai berikut :

1. Adaptor 12 volt

2. Dioda $1 \mathrm{~N} 4004$

3. Elco/ Capasitor 1000 uf

4. IC Regulator 7805

5. Resistor

6. Button

\section{Rangkaian keseluruhan}

Pada rangkaian keseluruhan dijelaskan mengenai keseluruhan rangakaian mulai dari catu daya, input, proses, output dan cara kerja alat. Rangkaian ini merupakan keseluruhan dari rancangan alat deteksi banjir menggunakan sensor kapasitif berbasis ATMega328p dan sms gateway

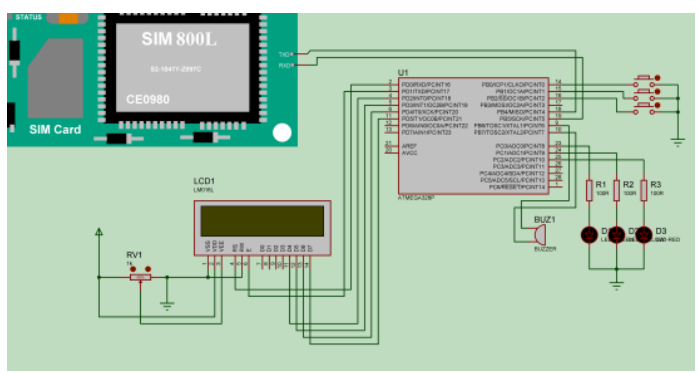

Gambar 5. Rangkaian Keseluruhan Alat Deteksi Banjir.

Alat deteksi banjir ini akan bekerja jika tinggi air mencapai batas batas yang telah ditentukan, maka setelah itu data akan dikelola oleh mikrokontroler ATMega328p dan hasil output-nya akan ditampilkan oleh LCD untuk menampilkan status air, LED menyala sesuai tingkat kewaspadaan, serta memproses modul GSM utuk mengirimkan informasi melalui SMS.

\section{Perencanaan Program}

Pada perencanaan program ini akan dijelaskan mengenai penggunaan flowchart program dan konstruksi program (Coding) pada alat deteksi banjir tersebut.

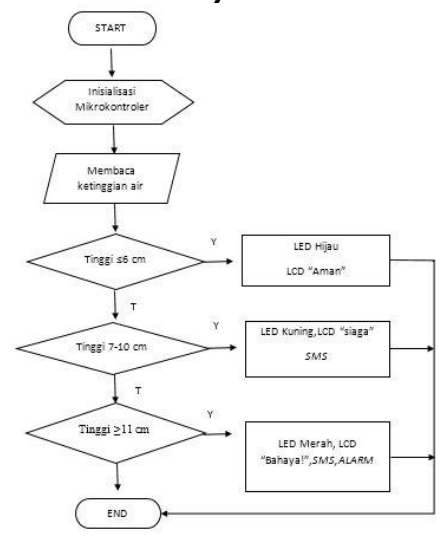

Gambar 6. Flowchart alat deteksi banjir.

Pada flowchart tersebut dijelaskan bahwa sensor kapasitif akan membaca ketinggian air, pada ketinggian $\leq 6 \mathrm{~cm}$ maka LED hijau menyala dan LCD menunjukkkan status "aman", kemudian pada ketinggian air mencapai 7-10 cm maka LED kuning menyala dan LCD menunjukkan status "siaga" serta mengirimkan SMS peringatan, dan pada ketinggian air mencapai $\geq 11 \mathrm{~cm}$ maka LED merah menyala dan LCD menunjukkan status "bahaya" lalu mengirimkan SMS peringatan serta buzzer berbunyi. Pengujian alat digunakan untuk mengetahui sejauh mana kinerja sistem yang telah dibuat dan memastikan bahwa alat yang dibuat berjalan dengan baik sesuai dengan perencanaan. Seperti mengetahui keluaran yang dihasilkan dari rangkaian catu daya, input, proses, dan output.

\subsection{Langkah Pengujian}

Langkah-langkah dalam pengujian alat deteksi banjir ini meliputi beberapa rangkaian yang harus dilakukan. Adapun langkah-langkah yang perlu diuji yaitu:

1. Pengujian sumber arus listrik

2. Pengujian sensor kapasitif

3. Pengujian LCD

4. Pengujian LED dan alarm

5. Pengujian Modul GSM

\subsection{Pengujian Catu Daya}

Pengujian catu daya ini berfungsi untuk mengetahui output daya yang keluar dari adaptor 12 V DC ini sesuai dengan 
yang dibutuhkan oleh alat deteksi banjir agar dapat berfungsi dengan baik. Pengujian dilakukan dengan menggunakan Untuk dapat mengetahui hasil output dari adaptor $12 \mathrm{~V}$ maka digunaka AVO meter untuk mengukur daya output. Dibawah ini merupakan hasil pengujian catu daya.

Tabel 1. Hasil Pengujian Catu Daya

\begin{tabular}{|c|c|c|}
\hline $\begin{array}{c}\text { Input } \\
\text { Daya }\end{array}$ & $\begin{array}{c}\text { Output } \\
\text { Daya }\end{array}$ & Keterangan \\
\hline PLN 220V & 12V DC & $\begin{array}{c}\text { Sesuai } \\
\text { Kebutuhan }\end{array}$ \\
\hline
\end{tabular}

\subsection{Pengujian Sensor Kapasitif}

Pengujian ini dilakukan dengan memberi daya sebesar 5V DC yang berasal dari IC 7805 untuk mengetahui seberapa akurat sensor kapasitif mampu mendeteksi tinggi permukaan air. Pada pengujian ini sensor kapasitif diberikan batas-batas tertentu untuk mendeteksi sesuai tingkat kewaspadaan air.

Tabel 2. Hasil Pengujian Sumber Daya Pada Sensor Kapasitif

\begin{tabular}{|c|c|c|}
\hline $\begin{array}{c}\text { Input } \\
\text { Daya }\end{array}$ & $\begin{array}{c}\text { Output } \\
\text { Daya }\end{array}$ & Keterangan \\
\hline 12V DC & 5 DC & Sesuai \\
\hline
\end{tabular}

Tabel 3. Hasil Pengujian Deteksi Sensor Kapasitif

\begin{tabular}{|c|c|c|}
\hline $\begin{array}{c}\text { Jarak } \\
\text { Pengujian }\end{array}$ & Indikator & Keterangan \\
\hline$\leq 5 \mathrm{~cm}$ & Menyala & Terbaca \\
\hline $6-10 \mathrm{~cm}$ & Menyala & Terbaca \\
\hline$\geq 11 \mathrm{~cm}$ & Menyala & Terbaca \\
\hline
\end{tabular}

\subsection{Pengujian Proses}

Pada pengujian ini dilakukan pada proses memasukkan program kepada mikrokontroler sebagai pusan perintah pada alat deteksi banjir ini. Jika proses memasukkan program berhasil maka alat deteksi banjir ini dapat berjalan dengan baik.

1. Langkah awal memasukkan program pada Mikrokontroler menggunakan kabel USB-UART ke komputer.

2. Kemudian jalankan software Arduino IDE, setelah itu pilih Port dan Board yang akan dimasukkan program pada menu Tools. Jika dipilih maka terjadi error pada saat proses memasukkan program. sumber daya PLN 220 V AC yang kemudian dihubungkan dengan adaptor 12 V DC.

3. Untuk memasukkan program bisa dilakukan dengan cara menekan tombol upload pada tool bar yang tersedia di Arduino IDE. Setelah tombol upload ditekan, software Arduino IDE akan melakukan proses compile dan memasukkan program ke mikrokontroler Atmega 328 yang akan diproses.

4. Setelah Program berhasil dimasukkan pada mikrokontroler maka program tersebut sudah dapat digunakan untuk alat deteksi banjir.

\subsection{Pengujian Output}

Pengujian output pada alat deteksi banjir untuk mengetahui kinerja LCD dan LED,pengujian ini dilakukan dengan memberikan daya sebesar $12 \mathrm{~V}$ DC yang berasal dari adaptor $12 \mathrm{~V}$ pada rangkaian LCD. fungsi LCD pada alat ini untuk menampilkan status berdasarkan tinggi permukaan air, sementara LED sebagai lampu indikator bahwa air telah memasuki batas-batas yang telah ditentukan dan apabila lampu indikator menyala pada warna merah maka suara alarm akan berbunyi tanda bahaya. Kemudian modul GSM akan mengirimkan sms jika air mencapai batas siaga dan bahaya.

Tabel 4. Hasil Pengujian Sumber Daya Pada LCD

\begin{tabular}{|c|c|c|}
\hline $\begin{array}{c}\text { Input } \\
\text { Daya }\end{array}$ & $\begin{array}{c}\text { Output } \\
\text { Daya }\end{array}$ & Keterangan \\
\hline 12 V DC & 12 V DC & Sesuai \\
\hline
\end{tabular}

Tabel 5. Hasil Pengujian Sensor, LED, Alarm, dan Modul GSM

\begin{tabular}{|c|c|c|c|c|c|}
\hline $\begin{array}{c}\text { Ting } \\
\text { gi }\end{array}$ & $\begin{array}{c}\text { Warn } \\
\text { a }\end{array}$ & LED & $\begin{array}{c}\text { Alar } \\
\mathrm{m}\end{array}$ & $\begin{array}{c}\text { SM } \\
\text { S }\end{array}$ & Ket \\
\hline $\begin{array}{l}\leq 5 \\
\mathrm{~cm}\end{array}$ & Hijau & $\begin{array}{c}\text { Meny } \\
\text { ala }\end{array}$ & $\begin{array}{c}\text { Tida } \\
\mathrm{k}\end{array}$ & $\begin{array}{l}\text { Tid } \\
\text { ak }\end{array}$ & $\begin{array}{c}\text { Terba } \\
\text { ca }\end{array}$ \\
\hline $\begin{array}{c}6-10 \\
\mathrm{~cm}\end{array}$ & $\begin{array}{c}\text { Kuni } \\
\text { ng }\end{array}$ & $\begin{array}{c}\text { Meny } \\
\text { ala }\end{array}$ & $\begin{array}{c}\text { Tida } \\
\text { k }\end{array}$ & $\mathrm{Ya}$ & $\begin{array}{c}\text { Terba } \\
\text { ca }\end{array}$ \\
\hline $\begin{array}{l}\geq 11 \\
\mathrm{~cm}\end{array}$ & $\begin{array}{c}\text { Mera } \\
\mathrm{h}\end{array}$ & $\begin{array}{l}\text { Meny } \\
\text { ala }\end{array}$ & $\mathrm{Ya}$ & Ya & $\begin{array}{c}\text { Terba } \\
\text { ca }\end{array}$ \\
\hline
\end{tabular}

\section{Kesimpulan}

Berdasarkan hasil perencanaan dan pembuatan alat serta dilakukan pengujian maka dapat diambil beberapa kesimpulan bahwa sistem otomatis deteksi 
banjir berdasarkan ketinggian air menggunakan sensor kapasitif berbasis mikrokontroler dan SMS gateway. Sistem deteksi banjir berikut komponen yang digunakan antara lain Sistem Minimum ATMega328p, Sensor Kapasitif, LED, LCD, Buzzer, dan Modul GSM. Dalam hal ini modul GSM dapat memproses dan mengirimkan SMS peringatan siaga dan bahaya ketika tinggi permukaan air mencapai batas yang telah ditentukan. Buzzer menyala tanda bahaya ketika pada batas aman maka LED hijau menyala, kemudian pada batas siaga maka LED kuning menyala dan mengirimkan sms peringatan, dan pada batas bahaya maka LED merah menyala, mengirimkan sms peringatan lalu buzzer menyala.

Diharapkan untuk penelitian dan pengembangan selanjutnya dapat dbuatkan alat atau system deteksi banjir berbasis android untuk proses pemantauan dan peringatan dari banjir yang terjadi secara realtime.

\section{Referensi}

Ayoma. (2015). Quickstart SIM 800L WITH ARDUINO. Diambil kembali dari WEBSITE AND BLOG OF AYOMA WIJETHUNGA:

http://www.ayoma.com

BNPB. (2017). Diambil kembali dari Data dan Informasi Bencana Indonesia (Online): https://www.bnpb.go.id/

Dasar, E. (2016). Sensor Kapasitif. Diambil kembali dari Elektronika Dasar: http://www.elektronika-dasar.web.id

Kho, D. (2014). Pengertian LED. Diambil kembali dari Teknik Elektronika: http://teknikelektronika.com/pengert ian-led-light-emitting-diode-carakerja/

Nuwaiir. (2009). Kajian Implementasi dan Kapasitansi Listrik Pada Membran Telur Ayam Ras.Skripsi. Bogor : Institut Pertanian Bogor.

Rachmad, T., Susanty, E., S, D. T., \& Nurlina, E. (11 Januari 2014). Gambaran Reselensi Anak Pasca Banjir di Desa Dayeuh Kolot, kabupaten Bandung, Jawa Barat.
Wacana Jurnal Psikologi Vol.6 no.11.

Undang- Undang Republik Indonesia Nomor 24 Tahun 2007 Tentang Bencana. (t.thn.).

Yulaelawati, E. (2008). Mencerdasi Bencana. Jakarta: PT.Grasindo. 